\title{
Temperature dependence of power generation of empty fruit bunch (EFB) based microbial fuel cell
}

\author{
Nazlee Faisal Ghazali a,*, Nik Azmi Nik Mahmood a, Noor Fadzilah Abu Bakar a , Kamarul Asri' \\ Ibrahim ${ }^{b}$ \\ a Department of Bioprocess and Polymer Engineering, School of Chemical and Energy Engineering, Universiti Teknologi Malaysia 81310 Johor \\ Bahru, Johor, Malaysia \\ ${ }^{b}$ Department of Chemical Engineering, School of Chemical and Energy Engineering, Universiti Teknologi Malaysia 81310 Johor Bahru, Johor, \\ Malaysia \\ * Corresponding author: nazlee@utm.my.
}

\section{Article history}

Received 5 May 2018

Revised 1 June 2018

Accepted 2 July 2018

Published Online 25 August 2019

\begin{abstract}
Microbial fuel cell has been considered a new emerging technology for renewable and sustainable electricity production. The energy can be extracted from organic waste materials which time independently increase in mass. In the present study, it was demonstrated that lignocellulosic material such as empty fruit bunch (EFB) can be used to produce electricity. Clostridium cellulolyticum and Bacilli E1 were used to activate EFB degradation and electricity generation respectively. It was also demonstrated that the present EFB based MFC was affected in terms of power produced with much higher power was obtained at $37.5{ }^{\circ} \mathrm{C}$ with power value of $825 \pm 3.08 \mathrm{~mW} / \mathrm{m}^{2}$ compared to 25 and $50{ }^{\circ} \mathrm{C}$, which produced $756 \pm 1.14$ $\mathrm{mW} / \mathrm{m}^{2}$ and $345 \pm 1.78 \mathrm{~mW} / \mathrm{m}^{2}$. At elevated temperature $\left(50{ }^{\circ} \mathrm{C}\right)$ showed decrease of power density value compared to lower temperature operated MFC, which is believed to be microbial metabolism dependent.
\end{abstract}

Keywords: Clostridium Cellulolyticum, bacillus E1, empty fruit bunch (EFB), microbial fuel cell

\section{INTRODUCTION}

Microbial fuel cells (MFCs) has been proven to generate electricity from diverse types of organic substrates ranging from simple carbohydrates (glucose, sucrose, cellulose, starch), volatile fatty acids (formate, acetate, butyrate), alcohols (ethanol, methanol), amino acids, proteins, and even inorganic components such as sulfides and nitrates (Pant et al., 2010). In terms of complex substrates such as wastewater, MFCs not only promised a proven concept for wastewater treatment but at the same time a method for capturing energy in the form of electricity or even hydrogen gas in-house. Furthermore, bacteria that can generate electricity (exoelectrogenic) through direct transfer of electron or mediator-based electron transfer is diversified due to the condition or nature of both electrolyte and substrate used (Lay et al., 2015; Rezaei et al., 2007).

Temperature is one of the important parameters to control in any fuel-related industries such as in anaerobic digesters, methane production, and wastewater treatment plants. In any cases, the capacity of the microbes used in the process could withstand the fixed temperature used. Some reports regarding anaerobic digesters revealed that most of them operated at the mesophilic temperature ( $\mathrm{Wu}$ et al., 2006; Gavala et al., 2003). It was reported that increment of temperature shows large improvement in terms of chemical oxygen demands (COD) and electricity production in MFCs to more than $90 \%$ removal and 10-fold increase, respectively (Jadhav and Ghangrekar, 2008; Larossa-Guerrero et al., 2010; Behera et al., 2011). This increment was possible due to the respond of anodic microbial metabolic changes as well as modification of other parameters involved in the design and operation of an MFC. In addition, at higher temperature, internal resistance in the MFC environment tend to decrease which will be an advantage when MFC is operated at elevated temperature (Behera et al., 2011). In contrast, a recent study reported that by decreasing the temperature as low as $10^{\circ} \mathrm{C}$, a sharp decrease in the voltage output was observed (Tang et al., 2014). However, further investigation is required to understand the behaviour of an MFC and how far metabolic response of microbial consortium presence affected due to physical changes such as temperature.

In the meantime, there are very few reports on complex substrate such as lignocellulosic biomass as source of fuel especially regarding its performance on the changes of temperature. So far, wastewater has been focused on extensively in the MFC studies which remains a loophole in the understanding of the nature of lignocellulosic based MFC. Thus, in the present study, empty fruit bunch (EFB)-based MFC was operated and its performance in power production by varying different temperature was investigated. The main results also include analyses on cellulose degradation aspects such as cellulose content, cellulose degrading enzymes activities (mainly cellulase), reducing sugar produced, and protein content. 


\section{EXPERIMENTAL}

\section{Materials}

Culture medium. In this study, the microbes chosen were already been used for lignocellulose based MFC (Ghazali et al., 2017). Bacilli E1 has been investigated previously for its ability to modulate the electricity generation and C. cellulolyticum has long been studied for its capability to convert cellulose to sugar. The medium used to grow strictly anaerobe $C$. cellulolyticum contained (per liter): $450 \mathrm{mg}$ $\mathrm{K}_{2} \mathrm{HPO}_{4}, 450 \mathrm{mg} \mathrm{KH} \mathrm{PO}_{4}, 900 \mathrm{mg} \mathrm{NaCl}, 900 \mathrm{mg}\left(\mathrm{NH}_{4}\right)_{2} \mathrm{SO}_{4}, 120 \mathrm{mg}$ $\mathrm{CaCl}_{2} \cdot 2 \mathrm{H}_{2} \mathrm{O}$, and $90 \mathrm{mg} \mathrm{MgSO}$. Cysteine- $\mathrm{HCl}(500 \mathrm{mg} / \mathrm{l})$ was added initially as an oxygen scavenger (Dehority, 2003). Meanwhile, facultative anaerobe Bacilli sp. E1 was cultured and maintained in commercially available Luria betani broth (MERCK). Medium for $C$. cellulolyticum was gassed with $\mathrm{N}_{2}$ for $1 \mathrm{hr}$ or otherwise stated to remove oxygen before subjected to autoclaving at $121{ }^{\circ} \mathrm{C}$ for $15 \mathrm{~min}$. All microbes were cultured until $\mathrm{OD}_{600}=1.0$.

Electrolyte for MFC operation. $0.1 \mathrm{M}$ Potassium phosphate buffer was used for anodic electrolyte with combination of $25 \mathrm{~mL}$ of $C$. cellulolyticum and Bacilli sp. mixture cell suspension. Importantly, the electrolyte was gassed with $\mathrm{N} 2$ for 15 min to remove oxygen and subsequently autoclaved.

\section{MFC construction and operation}

Single-chamber membrane-free MFCs $(250 \mathrm{~mL}$ in volume, with one circle-shaped for cathodic electrode and one rectangle shaped for anodic electrode using reticulated graphite cloth electrodes with $3.5 \mathrm{~cm}$ spacing from each other) were constructed as shown in Figure 1. The anodic electrodes surface area $20 \mathrm{~cm}^{2}$.

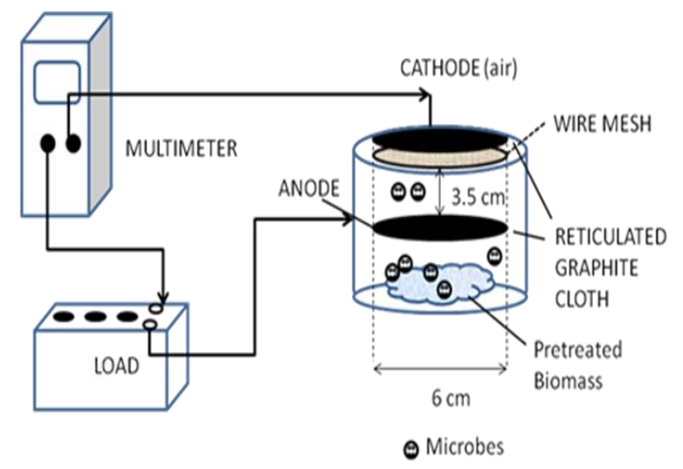

Figure 1 Schematic diagram of MFC.

The MFCs were inoculated with $2 \%$ (v/v) of Bacilli sp. E1 cultures at first operation in a batch-mode for 3 days in room temperature or otherwise stated, to acclimatize the bacterial to the $\mathrm{CMC}$ containing medium and forming biofilm to the anodic electrode. To reach a steady state, the MFC was operated at least twice to finally produce a repeatable potential difference or open circuit voltage (OCV). Subsequently, the old medium was flushed out and new medium was added with a $2 \%(\mathrm{v} / \mathrm{v})$ C. cellulolyticum. A control MFC was operated with both Bacilli E1 and $C$. cellulolyticum added without acclimatization. Both control and tested MFCs were changed to closed circuit mode by attaching a resistor box to conduct power generation analysis after finally reached a stable OCV. Power outputs were obtained at a fixed external resistance (10 to 100,000 Ohm) and observed for $30 \mathrm{~min}$ with each resistance. The resistances were run by first increased the resistance gradually then repeated with gradually decreasing the resistance applied. The measurement was observed through voltage produced using an auto-logged multimeter. Each subsequent MFC operation was flushed with nitrogen gas for 15 min to provide anaerobic environment. In addition, the temperature was varied and chosen based on the microorganism's growth profile, within the range of 25 to $50{ }^{\circ} \mathrm{C} .37 .5$ was interpolated from the range as a middle point of the temperature as well as representing the mesophilic microorganisms.

\section{Power analysis}

Voltage was measured using a digital multimeter. The current (I) and power $(\mathrm{P})$ were calculated based on Ohm's law which defined power $(\mathrm{P})=\mathrm{IV}$. Power density and current density were then calculated by normalizing calculated power with anodic surface area.

\section{Biochemical analysis}

Cellulose content. The cellulose content was estimated using Updegraff method (Updegraff, 1969). Briefly, $30 \mathrm{mg}$ of EFB were mixed with a mixture of acetic acid:water:nitric acid (8:2:1) and heated in a boiling water bath for $30 \mathrm{~min}$ with occasional thorough mixing. Then, the mixture was cooled prior to centrifugation to obtain pelleted substances and resuspended in $5 \mathrm{~mL}$ of distilled water. The process of centrifugation and resuspended in distilled was done twice before the remaining pellet was dissolved in $2.5 \mathrm{~mL}$ of $72 \%$ sulfuric acid for $1 \mathrm{hr}$ with subsequent vortexing every $5 \mathrm{~min}$. The resultant clear solution was then subjected to photometric measurement using Anthrone reagent at $620 \mathrm{~nm}$. Avicel (Sigma) was used as standard.

Cellulolytic enzyme assay. $5 \mathrm{~mL}$ of samples were taken from the MFC sampling port and were tested for cellulase activity. The cellulase assay was based on filter paper assay recommended by IUPAC (Ghose, 1987). Generally, the assay measures hydrolysis of cellulose both in crystalline and amorphous form which indicates endo- or exo- type of cellulase enzyme Briefly, a strip of filter paper (Whatman \#1, 50mg, 1 $\mathrm{X} 6 \mathrm{~cm}$ ) was reacted with $0.5 \mathrm{~mL}$ cellulase solution in a test tube with added $1.0 \mathrm{~mL}$ of $0.05 \mathrm{M}$ citrate buffer $(\mathrm{pH} 4.8)$ for one hour reaction at the given temperature prior to addition of $3.0 \mathrm{~mL}$ Dinitrosalycyclic solution, then boiled for $15 \mathrm{~min}$. The samples were filtered with a glass fiber filter paper before subjected to UV-Vis spectroscopic analysis at $540 \mathrm{~nm}$. Each sample was tested in replicates.

Reducing sugar concentration. Dintrosalicyclic acid-based assay was done by mixing $1.0 \mathrm{~mL}$ of sample from the MFC anodic liquid with $1.0 \mathrm{~mL}$ of dinitrosalicyclic acid solution (DNS) and incubated at $95{ }^{\circ} \mathrm{C}$ for $5 \mathrm{~min}$ before diluting it with $3.0 \mathrm{~mL}$ distilled water. Prior to cool, the samples were measured spectrophotometrically at $540 \mathrm{~nm}$ wavelength to estimate the reducing sugar concentration. Glucose was used to build a standard curve.

Protein determination. Biuret method was used to determine the protein concentration in MFC anodic liquid. The steps of Biuret assay were done according to the manufacture specification (Sigma-Aldrich).

\section{RESULTS AND DISCUSSION}

\section{Temperature effect on power generation}

The effect of operation temperature was investigated for the optimal condition of the MFC. MFC was operated for 3 days to achieve a stable or steady state of OCV which indicates the maximum achievable voltage for the present MFC system. Subsequently, different external resistant values were applied, and the highest CCV measured was at $10 \mathrm{Ohm}$, with the highest power density achieved at $756 \pm 1.14$, $825 \pm 3.08$ and $345 \pm 1.78 \mathrm{~mW} / \mathrm{m} 2$ in MFC operated at $25,37.5$, and $50{ }^{\circ} \mathrm{C}$, respectively (Figure 2). The obvious rule of Ohm's Law is that at lower resistance, power and voltage increased simultaneously. In addition, it was observed that at $50{ }^{\circ} \mathrm{C}$, the power produced were much lower compared to normal room temperature and condition that match the growth temperature for both microbes' presence in the MFC. This could suggest that either the microbes or the secreted cellulosedegrading enzymes were not able to withstand the elevated temperature. Furthermore, it seems that at $37.5{ }^{\circ} \mathrm{C}$, which was near optimum temperature for C. cellulolyticum (Petitdemange et al., 1984) and Bacilli E1 (not published), gave a high power and voltage that may indicate that the MFC efficiency depends on the microorganism's metabolic changes. Such observations also demonstrated with thermophilic microorganisms that shows little changes around the optimum temperature and drastically affected at lower temperature (Choi et al., 2004).

Further investigations supported the temperature effects at higher temperature with fixed external resistance (Figure 3). Low voltage was obtained at $50{ }^{\circ} \mathrm{C}$ with maximum value of $0.27 \pm 0.012 \mathrm{~V}$ compared to 37.5 and $25^{\circ} \mathrm{C}(0.422 \pm 0.007 \mathrm{~V}$ and $0.416 \pm 0.003 \mathrm{~V})$. 

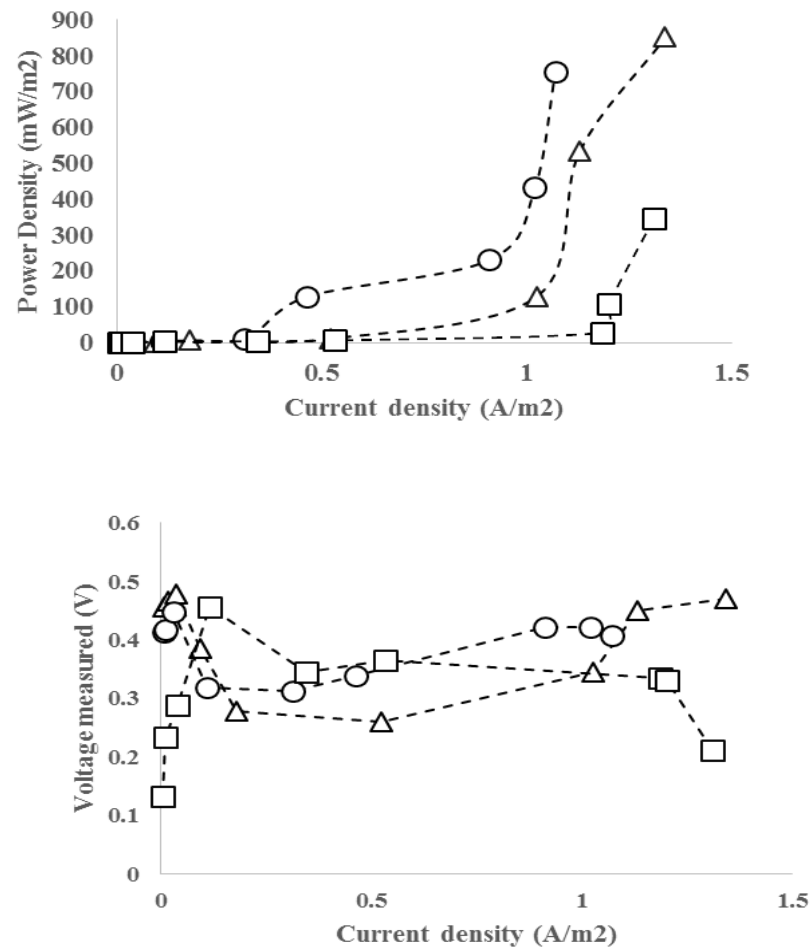

Figure 2 Temperature effect on voltage measured and power density on lignocellulose based MFC after applied different external resistance. Power density values calculated based on voltage measured (Above);

Voltage measured (Below). Temperature varied include ' $\square$ ', ' $O$ ' and ' $\Delta$ ' represents $25,37.5$ and $50{ }^{\circ} \mathrm{C}$, respectively. All MFC trials were done in triplicates.

\section{Biochemical evaluation}

The final cellulose content, remaining reducing sugar content and protein content were evaluated and summarized in Table 1.

Table 1 Hydrolysis of cellulose analysis in operated MFC.

\begin{tabular}{c|l|l|l|l}
$\begin{array}{c}\text { Temperature } \\
(\circ \mathbf{C})\end{array}$ & $\begin{array}{l}\text { Reducing } \\
\text { sugar }(\mathbf{m g})\end{array}$ & $\begin{array}{l}\text { Cellulase } \\
\text { Acitivity } \\
(\mathbf{U} / \mathbf{m L})\end{array}$ & $\begin{array}{l}\text { Protein } \\
(\mathbf{m g} / \mathbf{L})\end{array}$ & $\begin{array}{l}\text { Final } \\
\text { cellulose } \\
\text { content } \\
(\mathbf{w t} \%)^{\mathbf{a}}\end{array}$ \\
\hline 25 & $2.38 \pm 1.28$ & $0.822 \pm$ & $0.561 \pm$ & $28 \pm$ \\
& & 1.09 & 0.018 & 0.017 \\
37.5 & $3.08 \pm 2.33$ & $1.754 \pm$ & $0.991 \pm$ & $19.2 \pm$ \\
& & 1.33 & 0.032 & 0.126 \\
50 & $1.89 \pm 1.16$ & $0.323 \pm$ & $0.275 \pm-$ & $31 \pm$ \\
& & 1.29 & 0,026 & 0.033
\end{tabular}

a indicates the value obtained from reduction of initial cellulose concentration which is $38 \mathrm{wt} \%$.

Based on Table 1, higher reduction of cellulose obtained at $37.5{ }^{\circ} \mathrm{C}$, which was supported with the high cellulase activity in the MFC solution after operation. This was in accordance to the previous power curve and voltage data, and validate the high power and voltage produced at $37.5^{\circ} \mathrm{C}$. However, all cellulose content, especially at 25 and $37.5{ }^{\circ} \mathrm{C}$ were not completely converted to glucose or electricity, considering more than $70 \%$ of the cellulose still remains intact. It is known that high accumulation of cellulose degradation end product such as glucose and cellobiose will inhibit cellulase and decrease glucose yield (Hsieh et al. 2014; Valjamae and Teugjas, 2013). For this reason, it was probably that further degradation did not occur. In addition, at low enzyme concentration or low activity of cellulase continues to be a challenge for cellulose hydrolysis especially for complex biomass such as EFB and further investigation are needed to manipulate cellulase concentration by loading higher concentration of cellulose degrading enzyme or cellulase in MFC anode solution (Saddler and Arantes, 2010).

\section{CONCLUSION}

Temperature effect on the performance of EFB based MFC has been demonstrated and it was apparent that the MFC system was temperature dependent. The highest power production was observed at normal growth temperature range which was at 25 to $37.5{ }^{\circ} \mathrm{C}$ for mixed microorganisms used in this study. The cellulose concentration, cellulose degrading enzyme activities, and reducing sugar production in the MFC process were also affected by higher temperature, $50{ }^{\circ} \mathrm{C}$.

\section{ACKNOWLEDGEMENT}

This work was financially supported by the Universiti Teknologi Malaysia under the Research University Grant (QJ130000.2546.14H20 and QJ130000.2544.10H33)

\section{REFERENCES}

Behera, M., Murthy, S. S., Ghangrekar, M. M. (2011). Effect of operating temperature on performance of microbial fuel cell. Water Sci. Technol. 64 94): $917-922$.

Choi, Y., Jung, E., Park, H., Paik, S. R., Jung, S., Kim, S. (2004). Construction of microbial fuel cells using thermophilic microorganisms, bacillus licheniformis and Bacillus thermoglucosidasius. Bull. Korean Chem. Soc. 25(6): $813-818$.

Gavala, H. N., Angelidaki, I., Ahring, B. K. (2003). Kinetics and modelling of anaerobic digestion process. Adv. Biochem. Eng. Biotechnol. 81: 57 - 93.

Ghazali, N. F., Mahmood, N. A. N., Ibrahim, K. A., Nasaruddin, A. A. (2017). Preliminary studies on power generation By Bacilli E1 using Dual Chamber Microbial Fuel Cell. Malaysian J. Analytical Sci. 21(3): 669 - 674.

Ghose, T. K. (1987). Measurement of cellulase activity. Pure Appl. Chem., 59:257-268,

Hsieh, C-w., Canella, D., Jorgensen, H., Felby, C., Thygesen, L. G. (2014) Cellulase inhibition by high concentration of Monosaccharides. J. Agric. Food Chem. 62(17): $3800-3805$.

Jadhav, G. S., Ghangrekar, M. M. (2008) Performance of microbial fuel cell subjected to variation in $\mathrm{pH}$, temperature, external load and substrate concentration. Biores. Technol. 100(2): 717 - 723.

Lay, C-H., Kokko, M. E., Puhakka, A. (2015). Power generation in fed-batch and continuous up-flow microbial fuel cell from synthetic wastewater. Energy. 91: 235 - 241.

Larossa-Guerrero, A., Scott, K., Head, I. M., Mateo, F., Ginesta, A., Godinez, C. (2010). Effect of temperature on the performance of microbial fuel cells. Fuel. 89(12): 3985 - 3994.

McKeown, R. M., Hughes, D., Colins, G., Mahony, T., O’Flaherty, V. (2012) Low-temperature anaerobic digestion for wastewater treatment. Curr. Opi. Biotechnol. 23(3): $444-451$.

Pant, D., Van Bogaert, G., Diels, L., Vanbroekhoven, K. (2010) A review of the substrates used in microbial fuel cells (MFCs) for sustainable energy production. Biores. Technol. 101(6): 1533-1543.

Petitdemange, E., Caillet, F., Giallo, F., Gauddin, C. (1984) Clostridium cellulolyticum sp. nov., a Cellulolytic, mesophilic species from decayed grass. International J. Sys. Bacteriol. 34(6): 155 - 159.

Rezaei, F., Richard, T. L., Brennan, R. A., Logan, B. E. (2007). Substrateenhanced microbial fuel cells for improved remote power generation from sediment-based systems. Environ. Sci. Technol. 41(11): 4053 - 4058.

Saddler, J. N., Arantes, V. (2010) Access to cellulose limits the efficiency of enzymatic hydrolysis: the role of amorphogenesis. Biotechnol. Biofuel. 3(4) $1-11$.

Tang, J., Liu, T., Yuan, Y., Zhuang, Li (2014). Effective control of bioelectricity generation from a microbial fuel cell by logical combinations of $\mathrm{pH}$ and temperature. Sci. World J. 2014(5), 186016.

Teugjas, H., Valjamae, P. (2013). Product inhibition of cellulases studied with 14C-labeled cellulose substrate. Biotechnol Biofuel. 6(104): 3 - 14.

Truhlar, D. G., Kohen, A. (2001). Convex Arrhenius plots and their interpretation. Proc Natl Acad Sci USA. 98(3): 848 - 851.

Updegraff D. M. 1969. Semimicro determination of cellulose in biological materials. Anal. Biochem. 32:420-424.

Wang, W., Roberts, C. J. (2013). Non-arrhenius protein aggregation. AAPS J. 15(3): $840-851$.

Wu, M. C., Sun, K. W., and Zhang, Y. (2006) Influence of temperature fluctuation on thermophilic anaerobic digestion of municipal organic solid waste. J. Zheijiang Univ. Sci. B. 7(3): $180-185$. 